This work was supported by a grant from the National Heart Foundation of Australia.

Department of Experimental Pathology,

W. E. STehbens

John Curtin School of Medical Research, Australian National University, Canberra.

I Stehbens, W. E., Amer. J. Path., 43, 969 (1963).

' Boyd, G. S., and Oliver, M. F., in Cholesterol, edit. by Cook, R. P., 181 (Academic Press, New York, 1958).

${ }^{3}$ Stehbens, W. E., Amer. J. Path., 36, 289 (1960).

${ }^{4}$ Pearse, A. G. E., Histochemistry, second ed., 320 (J. and A. Churchill, Ltd., London, 1960)

' Wilens, S. L., Amer. J. Path., 27, 825 (1951)

${ }^{6}$ Prior, J. T., and Jones, D. B., Amer. J. Path., 28, 937 (1952).

' Dock, W., J. Amer. Med. Assoc., 131, 875 (1946).

${ }^{8}$ Moon, H. D., Circulation, 16, 263 (1957).

${ }^{9}$ Levene, C. I., J. Path. Bact., '72, 79 (1956).

${ }^{10}$ Hassler, O., Acta Soc, med, upsalien., 67, 35 (1962).

1 Robertson, J. H., J. Clin. Path., 13, 133 (1960).

12 Duff, G. L., Arch. Path., 20. 81. 259 (1935).

\section{Inhibition of Tumour Growth in Irradiated Mice by Sensitized Homologous Spleen Cells}

I $T$ is known that tumours possess antigens which differ from those in normal tissue. Experimental evidence for this has been obtained by workers using chemically. induced tumours and others with a virus-induced tumour and spontaneous tumours ${ }^{1-3}$. It has also been shown, however, that the spontaneous $A$-strain carcinoma is not antigenic after repeated transplantation in the strain of origin ${ }^{4}$.

In this laboratory, where the long transplantable tumour $L .5178$ of $D B A / 2$ mice was used, the cytotoxicity of immune serum produced in rabbits tolerant to normal $D B A / 2$ mouse tissue was recently demonstrated ${ }^{5}$.

In the work recorded here it was decided to examine the effect of homologous immune spleen cells on the same mouse tumour. Fifteen $D B A / 2$ mice were divided into three groups of five and treated as follows: (1) wholebody irradiation $(600 \mathrm{r}$.) followed by intra-peritoneal inoculation of $L-5178$ tumour 3 days later, followed $1 \mathrm{~h}$ later by intra-peritoneal inoculations of homologous immune spleen cells; (2) whole-body irradiation followed by intra-peritoneal inoculation of $L-5178$ tumour 5 days later; (3) no irradiation, intra-peritoneal inoculations of $L-5178$ tumour at the same time as in groups (1) and (2).

The dose of tumour given to each mouse consisted of 500,000 ascites cells in normal saline. The spleen cell inoculation consisted of a normal saline suspension of $64 \times 10^{6}$ viable cells, these being obtained from strain 129 mice immunized with live $L-5178$ cells.

It was found that the mean survival time in each of the three groups of mice was essentially the same, approximately 9 days from the time of tumour inoculation. The mice in groups (2) and (3) developed marked ascites together with solid tumour in the peritoneal cavity and histological evidence of extensive tumour infiltration of other organs. The mice in group (1), however, which had been treated with immune spleen cells, showed no ascites or solid tumour and no histological evidence of tumour or infiltration whatsoever. These results are summarized in Table 1 .

\begin{tabular}{|c|c|c|c|c|c|}
\hline \multirow{3}{*}{ Group } & \multicolumn{4}{|c|}{ Table 1} & \multirow{3}{*}{$\begin{array}{l}\text { Post-mortem } \\
\text { findings }\end{array}$} \\
\hline & & & Survival tin & & \\
\hline & Day 0 & Day 3 & Individual & Mean & \\
\hline 1 & Irradiation & $\begin{array}{l}L-5178 \text { in lym- } \\
\text { phoma cells } \\
\text { and spleen }\end{array}$ & $6,8,10,10,10$ & 9 & $\begin{array}{l}\text { No tumour cells } \\
\text { or ascites }\end{array}$ \\
\hline 2 & Irradiation & $\begin{array}{l}L-5178 \text { lym- } \\
\text { phoma cells }\end{array}$ & $6,6,9,10,10$ & 8 & $\begin{array}{l}\text { Heavy infiltra- } \\
\text { tion with } \\
\text { tumour and } \\
\text { marked }\end{array}$ \\
\hline 3 & $\begin{array}{l}\text { No irradi- } \\
\text { ation }\end{array}$ & $L-5178$ & $6,10,10,10,10$ & 9 & $\begin{array}{l}\text { ascites } \\
\text { Heavy infiltra- } \\
\text { tion with } \\
\text { tumour and } \\
\text { marked } \\
\text { ascites }\end{array}$ \\
\hline
\end{tabular}

It was considered that the failure to increase survival time in (1) was due to a graft-versus-host reaction rather than the effects of irradiation, and tumours played no obvious part in their deaths. Further experiments are being planned along lines suggested by Rabotti and Iossifides ${ }^{6}$. These workers suggested that the severity of the graft-versus-host reaction produced by a given dose of spleen cells was dependent on: $(a)$ dose of irradiation; (b) degree of histo-incompatibility; (c) time interval between dose of irradiation and administration of spleen cells.

This work was supported by the British Empire Cancer Campaign for Research. We thank Dr. F. T. Farmer for irradiating the mice.

Department of Microbiology,

Royal Victoria Infirmary,

Newcastle upon Tyne, 1.

$$
\begin{aligned}
& \text { P. S. Gardner } \\
& \text { C. A. H. Trench } \\
& \text { C. A. Green }
\end{aligned}
$$

Department of Pathology, General Hospital,

Newcastle upon Tyne, 4.

${ }^{1}$ Prehn, R. T., and Main, J. M., J. Nat. Cancer Inst., 181, 769 (1957). 2 Levi, E., Nature, 199, 501 (1963).

${ }^{3}$ Woodruff, M. F. A., and Symes, M. O., Brit. J. Cancer, 16, 120 (1962a). ${ }^{4}$ Woodruff, M. F. A., and Symes, M. O., Brit. J. Cancer, 16, 484 (1962b). ${ }^{5}$ Trench, C. A. H., Gardner, P. S., and Green, C. A., Brit. J. Cancer, 17, 287 (1963)

${ }^{6}$ Rabotti, G., and Iossifides, I., Nature, 197, 199 (1963).

\section{HISTOLOGY}

\section{Birefringence of Lymph Node Cells}

Is the course of work on the role of the lymphatic system in the rejection of homologous skin grafts, histological sections of rabbits' lymph nodes, prepared by a standard paraffin ombedding technique, were viewed under the microscope between two crossed polarizing filters. In certain sections, the nuclei of many cells were strongly birefringent (Fig. $1 a, b, c$ ). Perusal of the literature and conferences with colleagues have failed to uncover a previous description of this phenomenon. Because this finding might aid in investigations of nuclear structure, it is thought appropriate to report on it at this stage.

The cells which showed birefringence were most, but not all, of the large and small lymphocytes, as well as plasma cells and lymphendothelial cells. The nuclei of hæmocytoblasts were optically inactive, but some of these cells contained 1-3 small, round, perinuclear, birefringent bodies (Fig. 1b). No cell in mitosis showed birefringence. The germinal centres of the nodes, except for a few scattered cells, were conspicuously devoid of cells with optical activity, and contrasted sharply with the cuff of birefringent small lymphocytes around them (Fig. la).

Anisotropy of nuclei could only be observed in sections of nodes that had been fixed in absolute alcohol or Carnoy's fluid; formalin fixation inhibited it. It was seen in all unstained deparaffinized sections, and to a varying degree in all sections stained with methyl green-pyronin. Staining with hæmatoxylin and eosin completely blocked it. Exposure of an unstained, deparaffinized and rehydrated section to 10 per cent formalin abolished the birefringence.

Touch preparations consisting of whole cells, whether fresh or alcohol fixed, or frozen sections of fresh or alcohol fixed lymph nodes, did not show birefringence. A possible strain artefact, derived from the cutting procedure, has been ruled out as the cause for the birefringence (by $\mathrm{Mr}$. E. S. Emerson of the Polaroid Corporation, Cambridge, Massachusetts, whom I thank).

The meaning of this phenomenon is not yet clear. Because the observed anisotropy is entirely confined to 